\title{
SIGNS AND NARRATIVE DESIGN IN PLUTARCH'S ALEXANDER
}

\author{
$P$ Bosman (UNISA)
}

\begin{abstract}
Plutarch's Alexander reflects the tendency among earlier Alexander sources to augment the life of the great Macedonian with a supernatural aspect. Plutarch himself selects from, dismisses and fashions this material in accordance with his own standards for responsible biography, but also with his narrative purposes. This paper explores the relationship between signs from the supernatural sphere (semeia / theia, including dreams, oracles, omens, portents) and Plutarch's narrative line. In the initial section of the biography, Plutarch's deliberate association of his protagonist with divine involvement provides sanction for his future success. After establishing his character as 'spirited' (thymoeidess), the signs support his spirit (thymos) and ambition (philotimia) towards fulfilling his allotted role. During the latter part of the narrative, portents tend to become ominous, so that Alexander is depicted as dejected (athymos), anxious (tarachōēes; periphobos), despairing (dysthymos), and superstitious (deisidaimōn). In this way, the signs support an ascending and descending line in Alexander's biography and hint at divine and psychological (in addition to moral) reasons for Alexander's successes and eventual demise.
\end{abstract}

\section{Introduction}

The figure of Alexander generated one of the most extensive and influential bodies of literature in the whole of the ancient world. A good number of treatments of his life survived, the important authors being Diodorus Siculus, Curtius Rufus, Plutarch, Arrian and Justin. These versions, from the first century BC and later, ultimately rely on sources contemporary and near-contemporary to Alexander himself (late fourth / early third century BC), such as Callisthenes, used by Aristobulus and Ptolemy, in their turn the principal sources of Arrian; and Onesicritus and Nearchus, used by Cleitarchus, who again served as source for the so-called 'vulgate' authors, Diodorus, Curtius and Trogus / Justin. ${ }^{1}$ But by the end of the first century $\mathrm{AD}$, a plethora of others were available to the historian and biographer. In his Life of Alexander, Plutarch mentions no fewer than twenty-four of these sources. Additionally, Plutarch is also indebted to rhetorical and philosophical treatments of Alexander. Finally, he disposes of a collection of

1 See Baynham 2003 for a recent brief discussion of the Alexander sources. 
letters by and to Alexander, which he treats as authentic and often as the final word on controversial issues. ${ }^{2}$

Plutarch's Alexander proved over centuries to be a very popular access point to the great Macedonian. Its popularity is in no small measure due to his inclusion of anecdotal and legendary material such as that on Alexander's birth and youth. Despite serious historians' low opinion of such stories, they have shown themselves able to stir the imagination of a wide readership. Among these may be counted frequent references to signs, portents and dreams which add colour, suspense and mystery: in sum a supernatural aspect to the narrative. ${ }^{3}$ While Plutarch discourages an exaggerated picture of the Macedonian and more than once counters fantastical stories with more sober accounts from the letters or some other source, he nonetheless retains far more of a supernatural dimension in the Alexander biography than in the parallel Life of Caesar. ${ }^{4}$ This article argues that Plutarch's inclusion of such reports relates to his narrative design, that is, to how he wished to depict the progression of Alexander's life. ${ }^{5}$

\section{The biographer at work}

Plutarch's access to so many diverse accounts of Alexander (Baynham 2003:4 refers to a 'great, noisy crowd of ancient authors') no doubt contributed to the layeredness (Hamilton 1969:xxxvii) and ambiguity (Wardman 1955:97) of his own version. In his Parallel Lives, he remains very much dependent on his sources, which consequently determine the various characters of his Lives to a large extent regarding both content and form (Russell 1973:100-116; Hamilton 1969:xxxiiixlix). That does not allow us, however, to reduce Plutarch to a mere cut-and-paste

2 For Plutarch's use of sources in the Alexander, cf. Hamilton 1969:xlix-lxii; Hammond 1993:5-187. The authenticity of the Alexander correspondence is disputed, although Hamilton 1969:lix-lx regards some at least as genuine; see also Baynham 2003:5. The philosophical / rhetorical interpretations of Alexander's life evidently exerted considerable influence on Plutarch's depiction; cf. Hamilton 1969:lx-lxi.

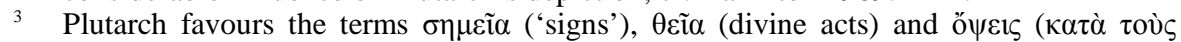

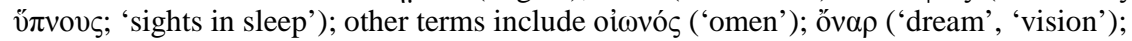
$\varphi \alpha ́ \sigma \mu \alpha$ ('apparition'); $\tau \dot{\varepsilon} \rho \alpha \varsigma$ ('portent'). The communication between the divine and

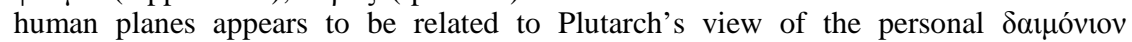
('genius'); cf. Alex. 14.8; 57.5; on the latter, see Brenk 1986:2117-2130; 1987:305-316; Deuse 2010:191-193; Dillon 2010:143-144; Schröder 2010:145-168.

4 Dreams and portents are not a conspicuous feature of the Caesar: only twice is reference made to $\sigma \eta \mu \varepsilon i \alpha$ in the sense of 'portents': 47.1 and 5, and 63.1, as opposed to the 13 times in the Alexander; $\varphi \alpha ́ \sigma \mu \alpha$ occurs 5 times, 4 of which are in relation to Pompey and Brutus. On the unity of the two works, cf. Buszard 2008:185 note 1.

5 Cf. also Brenk 1987:318. 
historian, nor to regard source criticism as the only responsible way of reading the Lives. ${ }^{6}$ On the contrary, the author was very much involved in shaping his material. At the start of the Alexander (1.2), Plutarch famously observes that he writes Bior

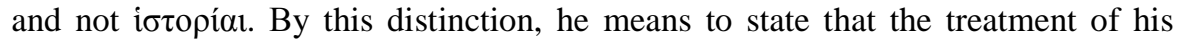
chosen subject would be neither exhaustive nor focus on the most illustrious deeds, but rather on those happenings which reveal character, even if they are of slight historical significance. Like a painter focusing on the face and the eyes of the person he wishes to portray, so Plutarch devotes himself to the character ( $\tilde{\eta} \theta 0 \varsigma)$ and

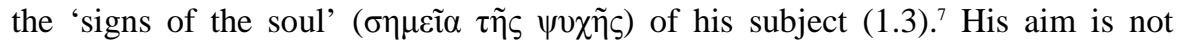
identical with that of modern biographical writing, but is rather to explore the "way of life' (Russell 1973:102) of his chosen figure, that is, to show 'what sort of a man

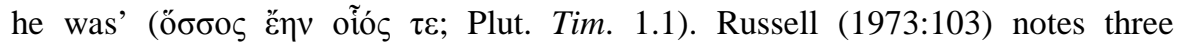
characteristics of Plutarch's understanding of writing biography: (1) the overall arrangement may be chronological, but that is of secondary importance; facts are presented in support of a general judgement; (2) it is concerned with an evaluation of the figure's virtues and vices, 'as shown in the mind's control of passion within and the whole man's emotional reaction to what besets him from without'; and (3) it is not concerned with the historical significance or influence of the figure, but solely with 'individual human qualities'. We may be sure that, while Plutarch would be at pains not to distort his sources, he may certainly be expected to have given the material his own spin, selecting, suppressing and slanting it in accordance with his narrative purposes. Consequently, an enquiry about the literary reasons for the many references to supernatural involvement in the Alexander seems legitimate.

Before moving to Plutarch's own motivations, the historical reasons for Alexander's association with the divine realm need to be accounted for. No doubt Macedonian religiosity played its part in the visits to oracles, frequent sacrifices and the team of seers ( $\left.\mu \alpha v^{\prime} \tau \varepsilon 1 \zeta\right)$ looking for the gods' favour in sacrificial entrails and the movement of birds, visions and dreams. ${ }^{8}$ As king, Alexander was in charge of the religious life of his people (Fredricksmeyer 2003:256-260). Then Alexander himself seems to have promoted the idea of his own divinity, just as his father Philip was about to proclaim himself the thirteenth god in the Macedonian pantheon on the day of his death (Diod. 16.92.5). It appears that the Macedonian

6 For a brief survey of scholarship and the later $20^{\text {th }}$ century turn in reappraising Plutarch as creative author, cf. Duff 1999:5-9; see also Pelling 1995.

7 Duff 1999:20-21 claims that this particular distinction between history and biography is meant to apply specifically to the Alexander, in order to distinguish his treatment from other works on the theme.

8 Fredricksmeyer 2003:253 notes that we know more about the religiosity of Alexander than of any other person in antiquity. 
royalty at that stage of heightened nationalistic feelings and rapid growth in power were subject to a sort of religious fundamentalism and a sense of their own destiny: they saw themselves as linked to the heroic past, as descended from the gods, and as having a mission to accomplish. ${ }^{9}$ These ideas left their mark on the Alexander reports.

Alexander's extraordinary accomplishments also played their part. Even Polybius, who in general is not favourable to Alexander, concedes that he was 'of

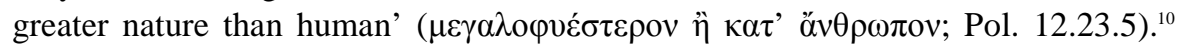
One can expect that stories about his superhuman qualities and fantastical exploits sprung up rapidly and abundantly. ${ }^{11}$ We may assume that some stories arose deliberately, according to Eratosthenes to please Alexander (Plut. Alex. 3.3; Arr. 5.3.1; Strabo 15.1.7-8). Onesicritus is one of the primary sources implicated in deliberate myth-making (Plut. Alex. 46.4; Strabo 15.1.28 calls him the "chief pilot of lies'). Plutarch mentions Onesicritus as one of a host of authors who relate a meeting between Alexander and the queen of the Amazons, which Plutarch himself characteristically rejects in favour of a letter of Alexander to Antipater, in which Alexander tells of an offer by the Scythian king to marry his daughter but omits any mention of the Amazon (46.1-3; cf. Romance 3.25-27). ${ }^{12}$

Another such incident provides an interesting case study in the growth of a legend: Alexander's passage down the coast of Pamphylia, in the words of Plutarch 'became to many historians a vivid pretext for alarm and exaggeration' ( $\pi \mathrm{o} \lambda \lambda_{\mathrm{o}} \mathrm{i} \varsigma$

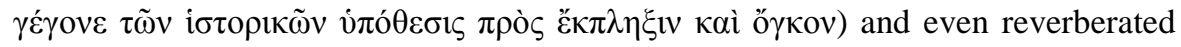
on stage in a Menander play (17.6-7). ${ }^{13}$ Cleitarchus must have given a nonsensational account of what happened, as Diodorus does not bother to mention it and Strabo's version (14.3.9) is without any reference to divine intervention. Callisthenes, on the other hand, compared the retreating sea to an act of

9 The Macedonians viewed Macedon, son of Zeus, as their founding father, while the royal house claimed to be direct descendants of Heracles; Hdt. 8.137; Thuc. 2.99; see Fredricksmeyer 2003:256, also 261 n. 29 for ancient references on the Macedonian idea of the war against Persia as religious crusade.

10 For an appraisal of Polybius' view of Alexander, see Billows 2000:289.

11 Billows 2000:288 n. 4 notes that all the Alexander historians share this feature of marvellous invented stories illustrating Alexander's superhuman nature.

12 Plutarch's mention of the story, only to discard it, is typical of his technique: while acknowledging that the story's truth or falsity is immaterial to our estimation of

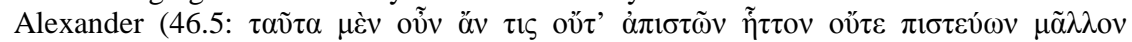

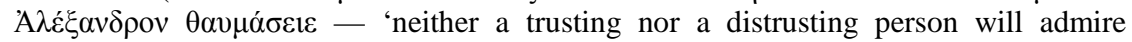
Alexander less or more due to these stories') he nevertheless includes it in his narrative; cf. Brenk 1987:318.

13 The term $A \lambda \varepsilon \xi \alpha v \delta \rho \tilde{\omega} \delta \varepsilon \varsigma$ in the Menander quotation gives evidence of the reputation of the Macedonian's luck and could have been coined by the playwright. 
$\pi \rho 0 \sigma \kappa v v \eta ́ \sigma 1 \varsigma$ (FGrH $124 \mathrm{~F} \mathrm{31})^{14}$ and Arrian says that the change of winds occurred

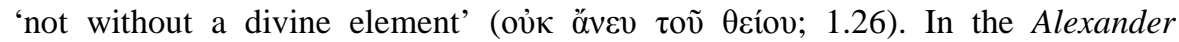
Romance it has become a miracle. ${ }^{15}$ Plutarch himself soberly dismisses any supernatural intervention, again employing the Alexander correspondence in support. ${ }^{16}$

Many instances of belief in divine intervention are not questioned by Plutarch, simply because they are congruent with his own beliefs. These include oracular directives, augury, oneiromancy and haruspicy. Plutarch also does not have scruples to mention strange or coincidental happenings which the ancients would consider as portents of greater or lesser plausibility. But he does more than once refer to claims of Alexander's divinity only to dismiss or at least deflate them. ${ }^{17}$ It may be asked, therefore, why these are included in the first place. The easy answer would be that Plutarch feels obliged to reflect the contents of his sources even when not agreeing with them. But why then omit many other events also found in the sources? A more convincing and nuanced answer lies in Plutarch's aim to reveal character, also by association and implication. The stories that are included, we can be sure, made the cut to serve this aim.

Plutarch's technique is sophisticated. He characterises explicitly (by means of his own evaluations, those of other characters and through the voice of his main character) as well as implicitly (through his character's actions, discourses, contexts and past). ${ }^{18}$ A good example is the dialogue between Darius and the eunuch Teireos who fled back to Darius when the king's wife, Stateira, died in childbirth (Alex. 30.1-14). Here the narrator employs two characters, the antagonist himself, and a lowly character under duress and with first-hand information. When Darius laments the fact that the queen died a prisoner and was deprived of a royal burial, Teireos informs him that she did not lack anything in life or in death, 'for', he says, 'Alexander is as kind when in power as he is vicious when fighting'. When Darius then voices his suspicion that Alexander and his wife had sexual relations, the eunuch

throwing himself at his feet, begged him to refrain from doing an injustice to Alexander and shaming his dead sister and wife, and from denying himself the greatest consolation in what he suffered, namely the belief to

14 Pearson 1960:36 suggests that the remark originated with the scholiast; cf. Hamilton 1969:44.

15 'In the latter (= [Pamphylia]) a miracle occurred: Alexander had no ships, but part of the sea drew back so that his army could pass on foot'; 1.28, trans. Stoneman 1991:61.

16 In this letter Alexander only mentions that the army marched by way of the so-called Staircase $(\kappa \lambda i \mu \alpha \xi)$; for discussion and references cf. Bosworth 1980:164-166.

17 Plut. Alex. 3.2 and especially 27.5-28.3.

18 See Hamilton 1969:xl-xliii for a discussion of Plutarch's characterisation. 
have been defeated by a man superior to human nature (

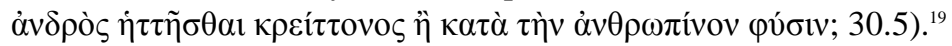

Plutarch may simply have summarised the whole scene from a source (neither Curtius nor Arrian's version has the same rhetorical spin), but makes effective use of the characterisation technique of employing a trustworthy outside witness, seemingly independent of the narrator's voice. It even allows Plutarch to retain an allusion to Alexander's divine nature which he otherwise either censures or treats circumspectly. ${ }^{20}$

Plutarch followed a particular hermeneutic when interpreting his sources. Like many of these, his portrayal of Alexander is apologetic and he rejected the attribution of base motives as a matter of principle. ${ }^{21}$ Apart from these considerations, he imposed a (or employed an already existing) narrative progression on his biography: the often-overlooked ascending and descending line of his portrayal. ${ }^{22}$ This narrative structure represents a deliberate authorial choice, since other structurings of Alexander's life existed alongside the up-down narrative. ${ }^{23}$ Onesicritus' 'philosopher in arms' probably had a much less conspicuous downward curve, as has Arrian's version (cf. Bosworth 1980:14). Other versions of Alexander's life were traditionally ascribed to the various Hellenistic schools. ${ }^{24}$ In the so-called Stoic use of Alexander as exemplum, he was from the start a victim of his $\tau \tilde{0} \varphi o \varsigma$ ('delusion', 'folly'), a slave to his passions and his inexhaustible craving for fame, wealth and power. ${ }^{25}$ The up-down line has been associated with the Peripatetics and in particular with Theophrastus. ${ }^{26}$ Rejection of an Aristotelian link with this particular narrative structure does not annul the

19 All translations are from the Loeb Classical Library.

20 In Curtius 4.10.18-34, relating the same episode, the threat of torture heightens the validity of the eunuch's (here Tyriotes) claim that Stateira was not violated by Alexander, but no mention is made of Alexander's 'more than human nature'.

21 Agesilaus 32-33; Pericles 28; Herodotus' Malice; cf. Russell 1973:60-61.

22 Hammond 1993:187 regards the deterioration of character in Plutarch as 'overdrawn'.

23 Hamilton 1969:lxiii notes that '[a]lmost all Plutarch's criticisms occur in the last part of the Life, for he recognized a deterioration in Alexander's character ...', a historical fact which 'even Tarn ... admits' (1969:lxv), but adds, significantly, that Plutarch underestimates the degree to which his savagery and ruthlessness were part of his makeup from the start (1969:xvi).

24 This approach fell out of favour among scholars; cf. Stoneman 2003:328-338, but see also Scardigli 1995:7-12 on peripatetic influence on Plutarch.

25 Stroux 1933; Wardman 1955:95; criticised by Fears 1974.

26 The Peripatetics were supposed to hold that Alexander was taught well, but became at some stage the victim of his passions, resulting in the murder of Callisthenes, the nephew of Aristotle, which in its turn had a significant effect on sentiment towards Alexander within Aristotelian circles. There was criticism against this view by, among others, Badian 1958:144-147; cf. also Stoneman 2003:328-329. 
existence of an interpretation of Alexander in which he was exceedingly lucky up to a point (Persepolis, to be precise; cf. Cic. Tusc. 3.21, 5.25; Att. 13.28.3) and then spoilt by that same fortuna and by the wealth and soft living of the orient. ${ }^{27}$ In the twin rhetorical treatises On the fortune or the virtue of Alexander, Plutarch argues against this view, but it remains conspicuous that the first signs of deterioration in Plutarch occur after Persepolis (Alex. 42:2-4; Wardman 1955:101).

Wardman (1955:97; 102-103) has drawn attention to the psychology employed by Plutarch at the start of the Life, which may be considered a key to his

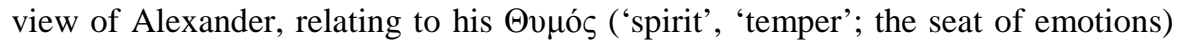

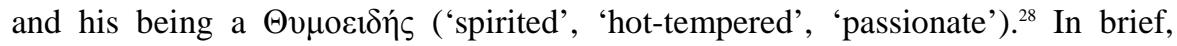

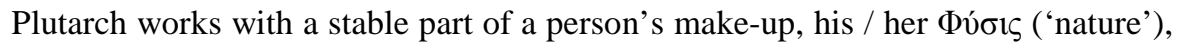
and an impressionable part, his / her $\tilde{\eta} \theta$ o $\varsigma$ ('disposition', 'character'). ${ }^{29}$ A brief character commentary (Alex. 4.5), inserted between a description of Alexander's physique and anecdotes about his youth, provides important insight into the

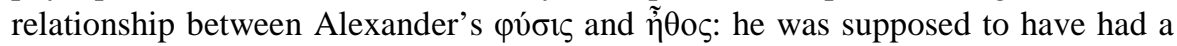

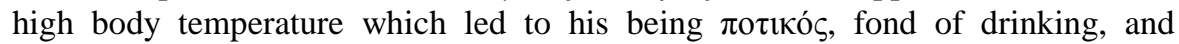

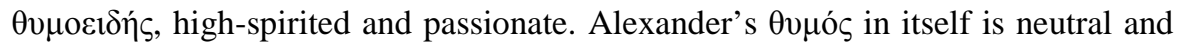
can lead to either virtue or vice. During the first part of the Life, it fuels his

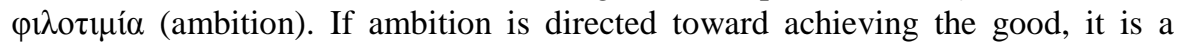
valuable attribute; if, however, it becomes a goal in itself, it leads to corruption. In the second part of the Life, Alexander's $\theta v \mu$ ó $̧$ frequently lapses into overzealous concern for his reputation, to anger, hubris, Dionysian excesses and anxiety. ${ }^{30}$

27 Curtius is quite specific with his dating of Alexander's moral degeneration: Sed ut primum instantibus curis laxatus est animus militarium rerum quam quietis otiique patientior, excepere eum voluptates, et quem arma Persarum non fregerant vitia vicerunt (6.2.1); Hic vero palam cupiditates suas solvit continentiamque et moderationem, in altissima quaque fortuna eminentia bona, in superbiam ac lasciviam vertit (6.6.1).

28 Hamilton 1969:1xiv criticises Wardman for attempting to 'explain his whole life in terms of this single quality'; to Hamilton, Plutarch's Alexander is a many-sided character. Russell 1973:106 likewise emphasises Plutarch's complex methods, making use of the theories and researches of the philosophers to create a multi-threaded Alexander. Such criticisms do not diminish the importance of the $\theta v \mu$ ó $\varsigma$ of Alexander as a running theme within the narrative. Cf. Plut. On moral virtue 442c-443d regarding his dependence on

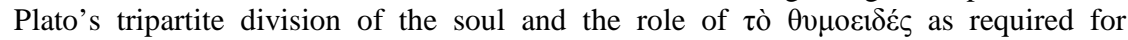
exercising virtue provided that it remains under reason's control; discussion of Plutarch's psychology in Duff 1999:72-98.

29 Cf. Duff 1999:74.

30 Mossman 1988:85 links the tension between negative and positive sides of $\theta 0 \mu$ ó $\varsigma$ (leading to either great achievement or disaster) to epic and tragic elements respectively. 
Divine involvement in the Alexander biography seems closely related to the theme of his $\theta v \mu$ óc. ${ }^{31}$ In terms of frequency, three clusters in which these interventions occur can be distinguished: the annunciation and birth narratives (2-3), the period from Issus to Gaugamela (17-34), representing the top of the curve, and the death omens at the conclusion of the Life (73-65). The sections inbetween are interspersed with prodigies and the like, but with less frequency than within these clusters, while significant sections do not contain any. It appears that the 'divine signs' function to establish Alexander's destiny to be the conqueror of Asia and to bolster his courage into fulfilling that destiny; when that was accomplished, the omens became ambiguous to bad, leading to a mood of $\dot{\alpha} \theta v \mu$ í $\alpha$ ('despondency', 'dejection') and $\delta v \sigma \theta v \mu i \alpha$ ('melancholy', 'despair').

\section{Annunciation and birth narratives}

The first cluster (2.1-3.9) starts with Alexander's descent from Heracles and Aeacus (2.1); one may assume his audience's familiarity with both as offspring of Zeus. Elsewhere, Plutarch makes mention of Alexander's admiration for the Iliad (8.2-3), for Achilles (15.7-9) and for Homer (26.3-7). But he seems intent not to force-feed his readership with Achilles-Alexander parallels, keeping the similarities he found in his sources subtle if not subdued. He makes virtually nothing of the Hephaestion-Patroclos parallel, very little of the sulking scene in his tent at the Hyphasis (62.5), while the Hector-Betis parallel at Gaza (Curt. 4.6.29) and the shield of Athena do not feature at all. ${ }^{32}$ The fact, however, that Alexander's divine and heroic origins are 'universally accepted' ( $\tau \tilde{\omega} \nu \pi \alpha ́ v v \pi \varepsilon \pi 1 \sigma \tau \varepsilon v \mu \varepsilon ́ v \omega v ; 2.1$ ) puts his character among the ranks of the heroes of old, whose interactions with the gods were more direct than in the present.

A religious overtone is sustained throughout the passage: Philip falls in love with Olympias after being initiated in the mysteries (2.2); the night before the marriage Olympias dreams of a thunderbolt falling upon her womb, kindling a fire that rapidly spreads and then gets extinguished (2.3). The dream functions as first prediction of Alexander's career, though still in vague terms. It also associates his

31 Divine involvement will in the following refer to the various $\sigma \eta \mu \varepsilon \tilde{\alpha} \alpha$ and $\theta \varepsilon \tilde{i} \alpha$ (omens, portents, oracles, visions and dreams), and instances of extraordinary occurrences and luck, suggesting divine interference in the natural order.

32 It may be that Plutarch chooses to be more subtle: the incident at Malli (63.4) does have

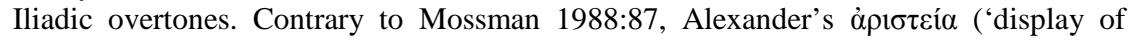
prowess') should rather be connected with Gaugamela (not the Granicus) where an inserted Homeric 'arming scene' (32.8-12) no doubt contributes to the extraordinary confused chronology, referred to by Tarn 1948:352 as 'the worst farrago of nonsense in the Greek language'; cf. Hamilton 1969:83 who tries to salvage the mess. 
character with fire, an association recurring later. Next comes Philip's dream of the lion seal on his wife's womb, after which the seer Aristander makes his first

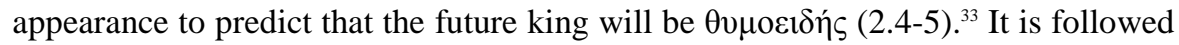
by the story of the serpent sleeping with Olympias (2.6-3.4), who is depicted as a religious ecstatic of the Dionysiac type (2.7-9), suggesting that a god was the real father of Alexander. ${ }^{34}$ Plutarch ends the section by seemingly throwing cold water on the rumours with a reported response from Olympias to the gossip: 'Shouldn't Alexander stop discrediting me with Hera?' (3.4). Her first-person response - for the sake of greater authority - is of course ambiguous, as it doesn't contradict the rumour, but rather suggests fear (or mock-fear) for Hera, should the truth come out. Neither does it deny the dreams and the serpent innuendos, but it does introduce a sense of sober reality into the foregoing myth. Plutarch, though not associating with these stories, wishes them to be associated with his Alexander anyway: the religious setting, the blurring of boundaries between human and divine, the associations of divine kinship, and the mysterious, Dionysiac tendencies of his mother all add to the supernatural aspect of the biography. ${ }^{35}$

Alexander's birth itself coincides with good omens of another kind. These are not by themselves supernatural, but they point to Alexander's future significance: the Artemis temple in Ephesus burns down (3.5-7), and Philip receives two other messages of good fortune: Parmenio has conquered the Illyrians and a horse of his wins at the Olympic Games (3.7-9). Both are interpreted by holy men as portents: the former by magi as pointing to impending disaster for Asia, the latter by Philip's seers that the boy will always be victorious. Plutarch gradually unpacks the detail regarding the future destiny of his character.

\section{The narrative climax: fulfilling destiny}

The second cluster may be demarcated as starting between the battles of the Granicus river and Issus, and continuing up to the success of Gaugamela (17-34). During this section Alexander is depicted as supremely fulfilling his destiny, even subduing fate itself, and brought to the borders of divinity. The portents serve to

33 On Aristander in the Alexander histories, cf. Greenwalt 1982.

34 See Ogden 2009 for a discussion of the myth and the original identity of the "siring snake'.

35 Plutarch employs a narrative technique found elsewhere in the 'vulgate' sources and probably in Cleitarchus: stories are 'recounted with some reserve, as though Cleitarchus was unwilling to present them as fact, but wished them to be known and to circulate'; Baynham 2003:16. The technique was widely used in imperial writing, most notably perhaps in Tacitus' treatment of the early principate in the Annals; see also Russell 1973:61. 


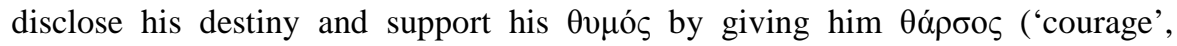
'confidence'). It starts with a prodigy after the Granicus battle which is intended to reiterate that history is about to be made (17.4-6): a spring in Lycia spouts forth a tablet predicting the destruction of Persia by the Greeks. Alexander is suitably

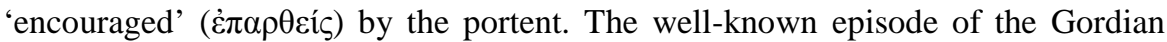
knot (18.1-4), which Plutarch presents as a chance happening, further establishes his destiny to become king of the world ( $\varepsilon i \mu \alpha \rho \tau \alpha$, 'allotted', 'decreed by fate').

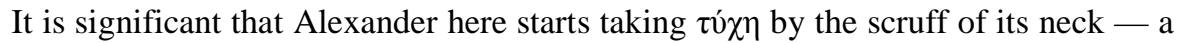
theme recurring a number of times during this narrative section.

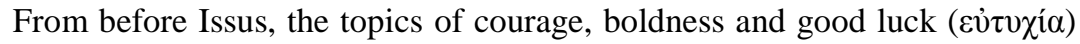
come in several forms. Entangled with these is the interplay between fate and ability. Plutarch mentions that while the Issus battleground was a gift of $\tau$ vo $\chi$ ('fate'), Alexander's generalship contributed even more to his victory

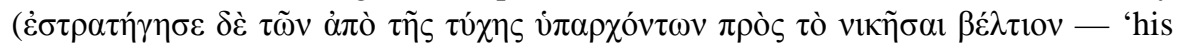
generalship counted more towards the victory than the circumstances due to fate'; 20:7-8). Much emphasis is placed in the next section (21.7-23.10) on Alexander's self-mastery and virtue, which remains intact due to his single-minded ambition

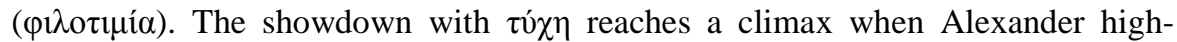
handedly changes the calendar in his zeal to uphold Aristander's interpretation of sacrificial entrails that Tyre would fall within the same month (25.1-3). The theme of being immune to and even subduing $\tau \dot{\chi} \chi \eta$ (cf. Curt. 10.5.35) is continued in what should certainly be regarded as one of the climactic passages of the biography (26.14), where the author states that:

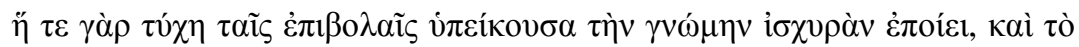

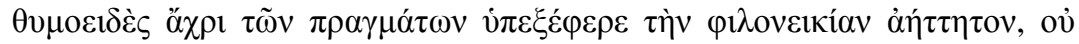

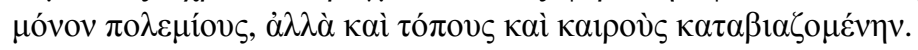

Fate, by yielding to his designs, was strengthening his resolve and his highspiritness converted into deeds rendered his love of victory invincible, forcibly subduing not only enemies, but also places and times.

The passage is followed by the trip to Siwah (26.10-27.11), during which Alexander receives such clear support from the god that it even overshadows the

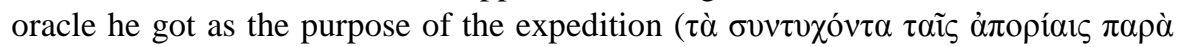

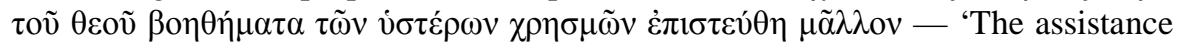
from the god encountered in difficulties was considered more trustworthy than the oracles which were to follow'; 27.1).

Of course he then receives the oracle itself, the importance of which Plutarch diminishes by giving three reasons why the incident should not be 
understood as indicating Alexander's divinity (27.8-11) ${ }^{36}$ Historically speaking, Alexander probably did believe in his own divinity. ${ }^{37}$ Plutarch, however, is adamant that Alexander only used the notion as a political ploy, summarising from the evidence of Alexander's own correspondence that 'Alexander evidently was neither affected nor deluded by the belief in his divinity himself, but rather

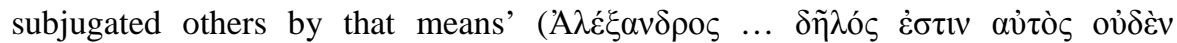

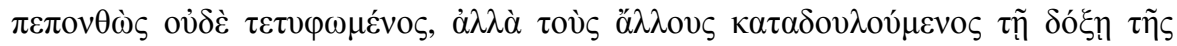

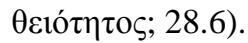

The narrative climax is sustained until the vivid, almost cinematic scene of Alexander at Gaugamela, accompanied by his seer Aristander and a soaring eagle, beseeching the gods for victory before and sacrificing to them afterwards (33.134.1), also proclaiming freedom to all the Greeks as a consequence of his ambition

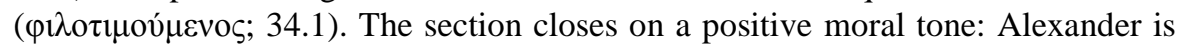

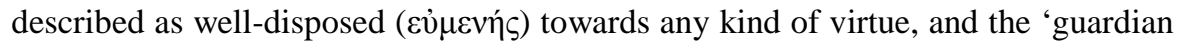

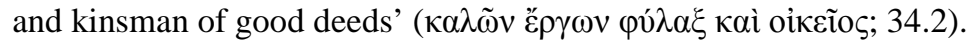

\section{The downward turn}

From here on things gradually change for the worse. Plutarch becomes less apologetic and the signs and omens, up till now encouraging, turn ambiguous to

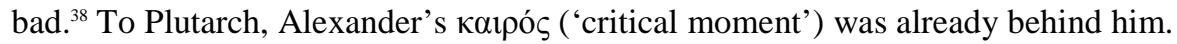
While his virtue held out (42.10), the weaknesses of a man who has already reached his acme start creeping in: distrust, ill-temperedness, anger, cruelty, dejection. ${ }^{39}$ There follow the deaths of Philotas and Parmenion, of Cleitus and Callisthenes, later on of Bucephalus and Hephaestion. The two omens before the murder of Cleitus (50.2-3), meant to exonerate Alexander, are nonetheless

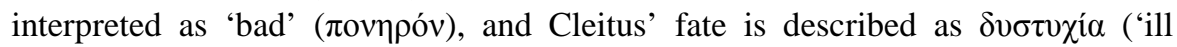
fortune'), due to his $\delta \alpha \mu$ óviov taking advantage of the king's anger and drunkenness (50.1). After the murder, with Alexander in utter despair over his own

36 The historical issues regarding Alexander's becoming a god in Egypt are beyond the scope of the present article; for a discussion challenging the scholarly consensus, see Collins 2009.

37 Cf. Fredricksmeyer 2003:274-278.

38 Plutarch's rather lengthy insertion of the Macedonians' encounter with naphtha directly after the victory at Gaugamela (35) is peculiar and should be regarded as a portent; its symbolic significance and relationship to the 'fiery' protagonist are yet to be explored.

39 Alexander is depicted as immune to the corrupting influence of wealth, but the corruption of those around him led him to become overly harsh in judgement, and irritable regarding his $\delta$ ' $\xi \alpha$ ('repute') caused him to become ill-tempered and cruel (42.4). 
deed, Aristander, in an attempt to revive his spirit, reminds Alexander that what had happened had 'long before been ordained' ( $\pi \alpha \dot{\lambda} \lambda \alpha \iota \kappa \alpha \theta \varepsilon 1 \mu \alpha \rho \mu \varepsilon ́ v \omega v ; 52.1)$.

The disconcerting portent of the lamb born with a tiara and testicles on its

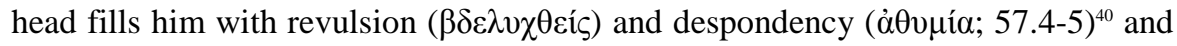
one cannot help feeling that when Alexander considered oil seeping from the ground as 'among the greatest of what the god has given him' (57.8), he is deliberately depicted as clutching at straws. Plutarch does not indicate why the omen put an end to his $\dot{\alpha} \theta v \mu i ́ \alpha$ (57.3) and pleased him so much (57.5), but does find it necessary to note that the seers were not unilaterally positive about the omen (57.9).

It would be misleading to present Plutarch's post-Gaugamela Alexander as simply doomed to failure; even in his narrative scheme much of the character's original resolve remains. Despite the hardships predicted by the seeping oil portent, Alexander still strove to 'overcome fate with courage and power with virtue,

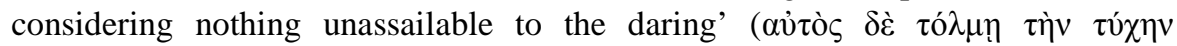

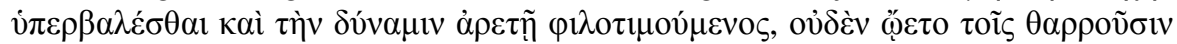
$\dot{\alpha} v \alpha \dot{\lambda} \omega \tau$ ov; 53.1). But mood swings become a regular part of his portrayal. At the

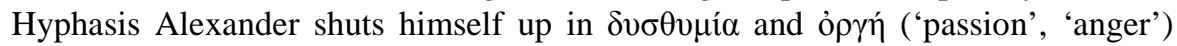
(62.5) and starts implementing all sorts of 'misleading and deceptive ways for the

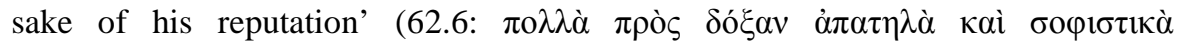
$\mu \eta \chi \alpha \nu \omega ́ \mu \varepsilon v o \varsigma)$. Among the Malli he is as reckless as at the Granicus and again almost pays the ultimate price, but this time with little glory attached (68.2-12). The disastrous trip through the Gedrosian desert, which other sources use to illustrate Alexander's leadership qualities, is almost hastened over (66.4-7); instead Plutarch tells in detail of a rowdy and disorderly drinking-party $(\kappa \tilde{\omega} \mu \circ \varsigma)$ lasting seven days on the way through Carmania, 'as though the god [Dionysus] himself were present and escorting the revel' (67.1-8). Hephaestion's death causes the king immense grief which he attempts to ease through cruelty (72).

In the final section of the biography, as Alexander approaches Babylon to meet his death (73-75), Plutarch portrays him as fully at the mercy of emotion. The section significantly includes a disproportionate number of signs either ominous themselves or at least interpreted to be foreboding. ${ }^{41}$ Chaldeans advise him to stay away from Babylon, which Alexander only heeds when a crow falls dead at his feet; the seer Pythagoras tells him of a sacrificial liver without a lobe, a tame donkey kicks one of his lions to death, a stranger claims that Serapis ordered him to go sit on the throne wearing the royal diadem and robes. Plutarch states that the

40 On this and other so-called 'birth omens', see Baynham 2000, esp. 252-254.

41 McKechnie 2009:217-220 lists thirteen such death omens, of which Plutarch includes five; ominous events 6 and 7 in McKechnie's Table 3 (2009:223-224) I would not regard as omens; see also Baynham 2000:254-255. 


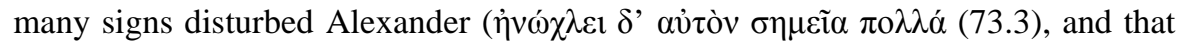

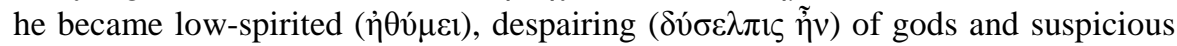
( sway of superstition:

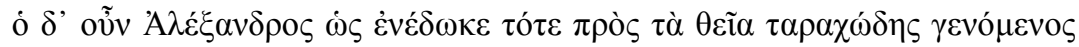

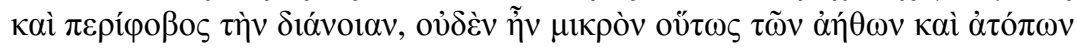

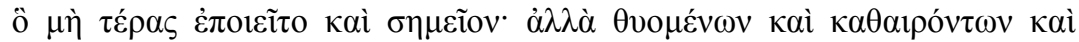

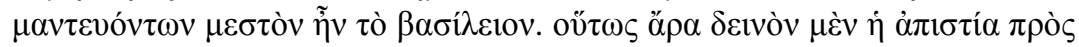

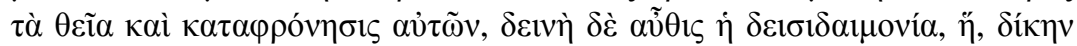

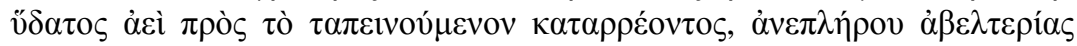

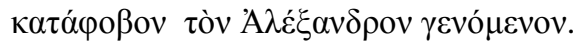

Thus Alexander from then on to such a degree gave in to the omens $(\theta \varepsilon \tilde{\alpha} \alpha)$, becoming disturbed and anxious in his mind, that he not only turned the slightest strange or unusual happening into a portent ( $\tau \dot{\varepsilon} \rho \alpha \varsigma)$ or a sign

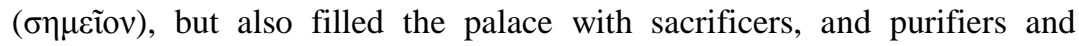
diviners. Distrust and contempt for divine signs $(\theta \varepsilon i \tilde{\alpha})$ are dangerous, but so is superstition, which, like water always flowing to the lower parts, filled a fearful Alexander with stupidity (75.1-3). ${ }^{42}$

By introducing the theme of superstition, Plutarch leaves the issue of divine favour for Alexander in the open to some extent: were the omens themselves indicating Alexander's imminent demise, or did his growing anxiety cause him to perceive divine disfavour where there was none? These questions are, however, not the main interest of the biographer, as he rather wishes to draw attention to the manner in which his character interacts with the divine signs. But the $\theta \varepsilon i \tilde{\alpha}$ nonetheless contribute to the famous atmosphere of doom and gloom that characterise the closing chapters of his biography (cf. Mossman 1988:91).

\section{Conclusion}

The foregoing analysis suggests the signs from the supernatural sphere in the Alexander to have three functions. Firstly, they create atmosphere and setting. At Alexander's birth, they indicate the significance of the child; during the height of his career they convey Alexander's glory; and at his end they show the anxiety and feeling of pending disaster. Secondly, they disclose the nature of Alexander's destiny, gradually becoming more specific: first he is likened to a spreading fire

42 In the treatise On superstition 165, Plutarch similarly describes fear as the cause of superstition. 
and his character is revealed as passionate and lion-like, then he becomes associated with disaster for Asia and finally with the downfall of the Persians. After Alexander has accomplished this, the omens become trivial and often signal bad things to come. Thirdly, they are linked to Alexander's $\theta 0 \mu$ ós: initially they provide the encouragement required for the fulfilment of Alexander's $\varphi \imath \lambda o \tau \imath \mu i \alpha$, but become the cause of despondency ( $\left.\dot{\alpha} \theta v \mu i{ }^{\alpha} \alpha\right)$, melancholy, despair and suspicion

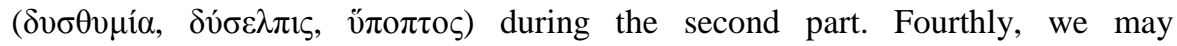
consequently say that they serve to support Plutarch's narrative line. The ascending and descending narrative design was originally created to illustrate Alexander's initial good fortune and how he was eventually corrupted by that. Plutarch rejects this view of Alexander's life, in its stead advocating the idea that Alexander was at first driven to fulfil his destiny and after that became - to simplify grossly something of a 'spent force'. To sustain this interpretation, he needed something inherent in his protagonist's psychological make-up to support the up-down curve. The divine signs provided a good part of the required scaffolding.

\section{BIBLIOGRAPHY}

Atkinson, J 2000. Originality and its limits in the Alexander sources of the early Empire'. In Bosworth, A B \& Baynham, E J (eds.), Alexander the Great in fact and fiction, 307-326. Oxford: University Press.

Badian, E 1958. Alexander the Great and the unity of mankind. Historia $7: 425-444$.

Baynham, E J 2000. A baleful birth in Babylon: The significance of the prodigy in the Liber de Morte - an investigation of genre. In Bosworth, A B \& Baynham, E J (eds.), Alexander the Great in fact and fiction, 242-262. Oxford: University Press.

Baynham, E 2003. The ancient evidence for Alexander the Great. In Roisman, J, Brill's companion to Alexander the Great, 3-30. Leiden: Brill.

Brenk, F E 1986. In the light of the moon: Demonology in the early imperial period. ANRW 2.16.3, 2068-2145.

Billows, R 2000. Polybius and Alexander historiography. In Bosworth, A B \& Baynham, E J (eds.), Alexander the Great in fact and fiction, 286-306. Oxford: University Press.

Bosworth, A B 1980. A historical commentary on Arrian's history of Alexander. Vol 1. Oxford: Clarendon Press.

Bosworth, A B 2000. Introduction. In Bosworth, A B \& Baynham, E J (eds.), Alexander the Great in fact and fiction, 1-22. Oxford: University Press.

Bosworth, A B \& Baynham, E J 2000. Alexander the Great in fact and fiction. Oxford: University Press. 
Brenk, F E 1987. An imperial heritage: The religious spirit of Plutarch of Chaironeia. ANRW 2.36.1, 248-349.

Buszard, B 2008. Caesar's ambition: A combined reading of Plutarch's AlexanderCaesar and Pyrrhus-Marius. TAPhA 138.1:185-215. The Johns Hopkins University Press.

Collins, A 2009. The divinity of Alexander in Egypt: A reassessment. In Wheatley, $\mathrm{P} \&$ Hannah, R (eds.), Alexander and his successors. Essays from the Antipodes, 179-205. Claremont, CA: Regina Books.

Deuse, W 2010. Plutarch's eschatological myths. In Nesselrath, H-G (ed.), Plutarch On the daimonion of Socrates, 169-197. Tübingen: Mohr Siebeck.

Dillon, J 2010. Pythagoreanism in Plutarch. In Nesselrath 2010:139-144.

Duff, T 1999. Plutarch's Lives: Exploring virtue and vice. Oxford: Clarendon Press.

Fears, J R 1974. The Stoic view of the career and character of Alexander the Great. Philologus 118:113-130.

Fredricksmeyer, E 2003. Alexander's religion and divinity. In Roisman, J, Brill's companion to Alexander the Great, 253-278. Leiden: Brill.

Greenwalt, W S 1982. A Macedonian mantis. Ancient World 5.1:17-25.

Hamilton, J R 1969. Plutarch Alexander: A commentary. Oxford: Clarendon Press.

Hammond, N G L 1993. Sources for Alexander the Great: An analysis of

Plutarch's Life and Arrian's Anabasis Alexandrou. Cambridge: University Press.

Hollmann, A 2011. The master of signs: Signs and the interpretation of signs in Herodotus' Histories. Washington DC: Center for Hellenic Studies. Hornblower, S 2002. The Greek world 479-323 BC. $3^{\text {rd }}$ ed. London: Routledge.

McKechnie, P 2009. Omens of the death of Alexander. In Wheatley, P \& Hannah, $\mathrm{R}$ (eds.), Alexander and his successors. Essays from the Antipodes, 179-205. Claremont, CA: Regina Books.

Mossman, J 1988. Tragedy and epic in Plutarch's Alexander. JHS 108:83-93.

Nesselrath, H-G (ed.) 2010. Plutarch On the daimonion of Socrates. Tübingen: Mohr Siebeck.

Ogden, D 2009. Alexander's snake sire. In Wheatley, P \& Hannah, R (eds.), Alexander and his successors. Essays from the Antipodes, 136-178. Claremont, CA: Regina Books.

Pearson, L I C 1960. The lost histories of Alexander the Great. London: Blackwell. Pelling, C B R 1995. Plutarch's adaptation of his source-material. In Scardigli, B (ed.), Essays on Plutarch's Lives, 125-154. Oxford: Clarendon Press.

Perrin, B 1971. Plutarch's Lives in eleven volumes Vol 7. LCL. Cambridge, Mass: Heinemann.

Roisman, J 2003. Brill's companion to Alexander the Great. Leiden: Brill. 
Russell, D A 1973. Plutarch. London: Duckworth.

Scardigli, B (ed.) 1995. Essays on Plutarch's Lives. Oxford: Clarendon Press.

Schröder, S 2010. Plutarch on oracles and divine inspiration. In Nesselrath, H-G (ed.), Plutarch On the daimonion of Socrates, 145-168. Tübingen: Mohr Siebeck.

Stoneman, R 2003. The legacy of Alexander in ancient philosophy. In Roisman, J, Brill's companion to Alexander the Great, 325-346. Leiden: Brill.

Stroux, J 1933. Die stoische Beurteilung Alexanders des Grössen. Philologus 88:222-240.

Wardman, A E 1955. Plutarch and Alexander. CQ 5.1,2:96-107.

Wheatley, P \& Hannah, R (eds.) 2009. Alexander and his successors. Essays from the Antipodes. Claremont, CA: Regina Books. 